\title{
comBÈs Isabelle, Diccionario étnico. Santa Cruz la Vieja y su entorno en el siglo XVI
}

\section{Vera Tyuleneva}

\section{OpenEdition \\ Journals}

\section{Edición electrónica}

URL: https://journals.openedition.org/jsa/11601

DOI: 10.4000/jsa. 11601

ISSN: 1957-7842

Editor

Société des américanistes

Edición impresa

Fecha de publicación: 5 diciembre 2010

Paginación: 309-311

ISSN: 0037-9174

\section{Referencia electrónica}

Vera Tyuleneva, "combès Isabelle, Diccionario étnico. Santa Cruz la Vieja y su entorno en el siglo xvI», Journal de la Société des américanistes [En línea], 96-2 | 2010, Publicado el 22 julio 2010, consultado el 03 septiembre 2022. URL: http://journals.openedition.org/jsa/11601 ; DOI: https://doi.org/10.4000/jsa. 11601

Este documento fue generado automáticamente el 3 septiembre 2022.

All rights reserved 


\title{
coMBÈs Isabelle, Diccionario étnico. Santa Cruz la Vieja y su entorno en el siglo XVI
}

\author{
Vera Tyuleneva
}

\section{REFERENCIA}

COMBÈs Isabelle, Diccionario étnico. Santa Cruz la Vieja y su entorno en el siglo XVI, Instituto de Misionología/Editorial Itinerarios, Cochabamba, 2010

1 Año 1561. Las costas del continente sudamericano son objeto de una veloz e intensa colonización, mientras sus interiores siguen siendo una terra incognita, poblada de seres extraños, atravesada por ríos desconocidos, llena de reinos ocultos, y rebosante de tesoros. En pleno corazón de este provocativo e inhóspito paisaje Ñuflo de Chaves, a la cabeza de un grupo de españoles venidos de la recién establecida Asunción de Paraguay, funda la ciudad de Santa Cruz (la Vieja) en los territorios que más tarde se llamarán Chiquitos o Chiquitanía, hoy Oriente de Bolivia. La nueva villa está destinada a ser la puerta y el trampolín para las conquistas de las presuntas tierras de metales preciosos y de fabulosa abundancia.

Los numerosos historiadores que han dedicado sus estudios a la historia de Santa Cruz y del Oriente Boliviano (entre ellos Enrique de Gandía 1935, Enrique Finot 1978, José María García Recio 1988), invariablemente han otorgado el rol protagónico en esos acontecimientos a los conquistadores, cuyas hazañas, envueltas en un romántico halo, se desarrollaban contra el obscuro trasfondo de la barbarie circundante. Poco se ha dicho sobre el contexto étnico de los grupos nativos en el que se incrustó la nueva colonia, grupos con los que coexistió en una estrecha relación y los que la abastecían sistemáticamente de provisiones, sirvientes y « noticias ricas ».

El exhaustivo y minucioso trabajo de Isabelle Combès tiene por objetivo llenar esta laguna y organizar el inmenso corpus de aislados y contradictorios datos sobre las etnias 
que se encontraban en la órbita de intereses de Santa Cruz la Vieja desde la fecha de su fundación en 1561 hasta el momento de su traslado hacia el oeste, a la margen izquierda del río Guapay, en 1603. En su alcance geográfico, el estudio no se limita a las inmediaciones de Santa Cruz, sino que se extiende a varios cientos de kilómetros a su alrededor.

El Diccionario... reúne en orden alfabético cientos de nombres de "naciones ", " generaciones », «parcialidades », «pueblos » y sus «principales », que figuran en los documentos cruceños de la segunda mitad del siglo xvi y comienzos del xvII. Una de las fuentes cruciales, que le proporcionó a la autora la mayor cantidad de material onomástico, es el Padrón de Encomiendas de Santa Cruz de 1561, reproducido íntegramente en el anexo del libro. Cada entrada del Diccionario... está encabezada por la grafía más común y frecuente de un determinado nombre, seguida por sus grafías alternativas. Los nombres van acompañados de sus respectivos contextos históricos y geográficos (más o menos extensos de acuerdo con la cantidad de datos disponibles) y de referencias a los documentos en los que están mencionados.

Los «Apuntes preliminares» que anteceden el Diccionario..., constituyen una amplia introducción de cincuenta páginas que abarca varios temas. En primer lugar, se le brinda al lector una noción general del estado de la cuestión, por cierto poco optimista. En el parco panorama de los estudios etnohistóricos referentes a la Chiquitanía del siglo xVI, se destacan las clásicas obras de Métraux (1942; 1948) sobre las tribus de Bolivia Oriental y los libros de Susnik $(1961 ; 1978)$. A continuación, Combès traza un esbozo histórico de las expediciones que dieron lugar a la fundación de Santa Cruz, poniendo acento en los grupos nativos con los que se topaban los expedicionarios.

6 La siguiente parte de la introducción está dedicada a las peculiaridades y dificultades de índole metodológica. Estos amplios comentarios ayudan a comprender el mecanismo del análisis de las fuentes empleado en el trabajo sobre el Diccionario... y resaltan los problemas con los que inevitablemente se encuentra todo investigador que elija el enmarañado campo de la etnohistoria amazónica. En el comienzo, la autora cuestiona los términos « etnia " y « etnónimo ", que se presentan algo borrosos incluso en aplicación a los contextos de la antropología actual, pero se disuelven por completo en los textos coloniales tempranos, repletos de "naciones", "pueblos» y "provincias». Esos términos, propios de la época, delimitan grupos humanos de una manera a menudo muy arbitraria, lejana de las modernas clasificaciones lingüísticas, culturales y geográficas. He aquí tan sólo algunas de las trampas que nos tienden las fuentes y contra las que nos previene Combès. En los textos del siglo xvi no se hacían distinciones claras entre el nombre de un determinado grupo y el nombre de la aldea en la que se concentraba. Los grupos grandes se confundían con sus respectivos subgrupos o " parcialidades ». A veces la supuesta denominación de una etnia no era más que un mecánico derivado del nombre de su "principal» (o de uno de sus "principales»). Con frecuencia un mismo grupo llevaba varios nombres, puestos por diferentes grupos vecinos. Partes de un grupo podían separarse, migrar en diferentes direcciones, asentarse en territorios nuevos y seguir conservando la misma denominación genérica. A todo eso se suma la dinámica diacrónica de los nombres, un reflejo de las múltiples migraciones, desplazamientos y cambios demográficos que en la mayoría de los casos han escapado al registro histórico.

7 Con todos estos peligros tomados en cuenta, la autora con audacia construye un cuadro de la distribución aproximada de diversos grupos en la geografía cruceña. El complejo mosaico resultante, está salpicado de nombres con escasas connotaciones, para los que 
no se conocen la filiación lingüística, o las características socioculturales, o la ubicación exacta. Pero en este nebuloso trasfondo sobresalen varios nombres de peso mayor, con rasgos más definidos: los xarayes y los paresis (o paressi) de habla arawak, con una sofisticada estructura política, habitantes de las cabeceras de los ríos Paraguay y Guaporé, respectivamente; los chané, otra rama de la familia arawak, que constituían el vínculo fundamental en el intercambio entre los Andes y Paraguay, especialmente en el tráfico de metales; $\mathrm{y}$, por supuesto, los omnipresentes grupos guaraní, mayormente los llamados chiriguana, separados en dos grandes ramas: los chiriguana itatines hacia el este y noreste de Santa Cruz la Vieja, y los chiriguana de la cordillera - los problemáticos vecinos del Tawantinsuyu - ampliamente conocidos por las crónicas andinas.

El Diccionario étnico... de Santa Cruz la Vieja es fruto de una labor titánica que ayuda a esclarecer el panorama etnohistórico de una amplia región en una determinada época. Aunque muchos de los puntos concretos planteados en este trabajo sin duda serán cuestionados con el tiempo, su valor fundamental consiste en crear la sólida base, el punto de partida para un futuro debate. Mientras tanto, las fuentes referentes a muchos otros territorios amazónicos permanecen en el estado del caos primordial, lleno de nombres mudos que parecen ser reacios a todo tipo de sistematización. Tenemos ahora una prueba tangible de que este caos es vencible.

\section{BIBLIOGRAFÍA}

\section{FINOT Enrique}

1978 Historia de la conquista del Oriente Boliviano, Librería editorial « Juventud », La Paz [1939].

\section{GANDÍA Enrique de}

1935 Historia de Santa Cruz de la Sierra. Una nueva república en Sud América, Talleres Gráficos Argentinos de L. J. Rosso, Buenos Aires.

GARCíA RECIO José María

1988 Análisis de una sociedad de frontera: Santa Cruz de la Sierra en los siglos XVI y XVII, Quinto centenario del descubrimiento de América, Publ. de la Excma. Diputación provincial de Sevilla, Sevilla.

\section{MÉTRAUX Alfred}

1942 The native tribes of eastern Bolivia and western Matto Grosso, Smithsonian Institution, Bureau of American Ethnology, Bulletin 134, Washington, DC.

1948 " The native tribes of eastern Bolivia and the Madeira headwaters ", in Julian H. Steward (ed.), Handbook of South American Indians, vol. 3, Smithsonian Institution, Bureau of American Ethnology, Bulletin 143, Washington, DC, pp. 381-454.

SUSNIK Branislava

1961 Apuntes de etnografía paraguaya, Museo etnográfico Andrés Barbero, Asunción.

1978 Los aborígenes del Paraguay. I: Etnología del Chaco Boreal y su periferia (siglos XVI y XVII), Museo etnográfico Andrés Barbero, Asunción. 


\section{AUTORES}

\section{VERA TYULENEVA}

Museo del convento de Santo Domingo, Qorikancha, Cusco 